\title{
The Inorganic Fluoride and Oxyfluoride Ferroelectrics
}

\author{
J. Ravez \\ Institut de Chimie de la Matière Condensée de Bordeaux, CNRS, \\ 162 avenue du Docteur Albert Schweitzer, 33608 Pessac Cedex, France
}

(Recenved 20 June 1996, accepted 12 November 1996)

PACS 77 80.-e - Ferroelectricity and antiferroelectricity

\begin{abstract}
The ferroelectric fluorides belong to six families of type $\left(\mathrm{NH}_{4}\right)_{2} \mathrm{BeF}_{4}, \mathrm{BaMnF}_{4}$, $\mathrm{SrAlF}_{5}, \mathrm{Na}_{2} \mathrm{MgAlF}_{7}, \mathrm{~K}_{3} \mathrm{Fe}_{5} \mathrm{~F}_{15}$ or $\mathrm{Pb}_{5} \mathrm{Cr}_{3} \mathrm{~F}_{19}$. The oxyfluorides can be separated in two groups: i) the true oxyfluorides with a relatively high $\mathrm{F} / \mathrm{O}$ value $\left(\mathrm{K}_{3} \mathrm{MoO}_{3} \mathrm{~F}_{3}, \mathrm{Na}_{5} \mathrm{~W}_{3} \mathrm{O}_{9} \mathrm{~F}_{5}\right.$, $\mathrm{Pb}_{5} \mathrm{~W}_{3} \mathrm{O}_{9} \mathrm{~F}_{10}, \mathrm{Bi}_{2} \mathrm{TiO}_{4} \mathrm{~F}_{2}, \ldots$ ); ii) the compositions derived from ferroelectric oxides (perovskite, tetragonal tungsten bronze, pyrochlore, $\mathrm{LiTaO}_{3}, \ldots$ ) characterized by a continuous $\mathrm{F}$-O substitution. The phase transitions and the physical properties are discussed The origin of the spontaneous polarization is described structurally. The variations of the Curie temperature with the type of substitution are related to chemical bonding. The potential interest of these materials for applications is briefly given.
\end{abstract}

Résumé. - Les ferroélectriques fluorés appartiennent à six familles de type $\left(\mathrm{NH}_{4}\right)_{2} \mathrm{BeF}_{4}$, $\mathrm{BaMnF}_{4}, \mathrm{SrAlF}_{5}, \mathrm{Na}_{2} \mathrm{MgAlF}_{7}, \mathrm{~K}_{3} \mathrm{Fe}_{5} \mathrm{~F}_{15}$ ou $\mathrm{Pb}_{5} \mathrm{Cr}_{3} \mathrm{~F}_{19}$. Les oxyfluorures peuvent être séparés en deux groupes : 1) les oxyfluorures "vrass" comportant un rapport $\mathrm{F} / \mathrm{O}$ relativement élevé $\left(\mathrm{K}_{3} \mathrm{MoO}_{3} \mathrm{~F}_{3}, \mathrm{Na}_{5} \mathrm{~W}_{3} \mathrm{O}_{9} \mathrm{~F}_{5}, \mathrm{~Pb}_{5} \mathrm{~W}_{3} \mathrm{O}_{9} \mathrm{~F}_{10}, \mathrm{~B}_{2} \mathrm{TiO}_{4} \mathrm{~F}_{2}, \ldots\right)$, i1) les compositions dérivées des oxydes ferroélectrıques (perovskite, bronze quadratique de tungstène, pyrochlore, $\mathrm{LiTaO}_{3}, \ldots$ ) et caractérisées par une substitution F-O continue. Les transitions de phases et les propriétés physiques sont analysées L'orıgine de la polarısation est précisée sur le plan structural. Les variations de la température de Curie avec le type de substitution sont relıées à des considérations de liaison chimique. L'intérêt potentıel de ces matériaux pour les applications est brièvement abordé.

\section{Introduction}

Inorganic ferroelectrics are mainly oxides (families KDP, perovskite, tetragonal tungsten bronzes, $\mathrm{LiNbO}_{3}$, pyrochlore, boracite, Aurivillius phases, ...). Ferroelectric fluorides are much less numerous; one of the causes is that although stable up to about $400 \mathrm{~K}$, the high temperature preparation of crystals and ceramics requires particular care to prevent hydrolysis. Some compounds are declared as ferroelectrics from theoretical studies $\left(\mathrm{HF}, \mathrm{PbF}_{2}, \mathrm{NaCaF}_{3}, \ldots\right)[1,2]$. Nevertheless the proofs of ferroelectric properties have been demonstrated only for the six following families: $\left(\mathrm{NH}_{4}\right)_{2} \mathrm{BeF}_{4}, \mathrm{BaMnF}_{4}, \mathrm{SrAlF}_{5}, \mathrm{Na}_{2} \mathrm{MgAlF} 7, \mathrm{~K}_{3} \mathrm{Fe}_{5} \mathrm{~F}_{15}$ and $\mathrm{Pb}_{5} \mathrm{Cr}_{3} \mathrm{~F}_{19}$. 
The ferroelectric oxyfluorides form a bridge between the fluoride and oxide families; the corresponding research has been on the increase for about forty years:

\begin{tabular}{|c|c|c|c|}
\hline \multicolumn{4}{|c|}{ Number of publications on oxyfluoride ferroelectrics } \\
\hline $1957-1966$ & $1967-1976$ & $1977-1986$ & $1987-1996$ \\
\hline 5 & 16 & 39 & $59 \ldots$ \\
\hline
\end{tabular}

These materials may be separated in two sub-groups:

- the "true" ferroelectric oxyfluorides with a relatively $\mathrm{F} / \mathrm{O}$ ratio and belonging to families in which fluorides and oxides are not necessarily ferroelectrics; as an example $\mathrm{Na}_{5} \mathrm{~W}_{3} \mathrm{O}_{9} \mathrm{~F}_{5}$ is ferroelectric although $\mathrm{Ca}_{5} \mathrm{Te}_{3} \mathrm{O}_{15}$ and $\mathrm{Na}_{5} \mathrm{Al}_{3} \mathrm{~F}_{14}$ are not;

- oxyfluorides derived from ferroelectric oxides by a generally progressive and weak fluorineoxygen substitution.

Table I gives the list of main fluoride and "true" fluoride families known at the present time.

\section{The Ferroelectric Fluorides}

2.1. $\left(\mathrm{NH}_{4}\right)_{2} \mathrm{BeF}_{4}$. - Ammonium fluoroberyllate is the longest known ferroelectric fluoride [3]. Its crystalline network is composed of distorted $\left(\mathrm{BeF}_{4}\right)^{2-}$ tetraedra. Although of close structure, however it is not isomorphous of the ferroelectric sulfate $\left(\mathrm{NH}_{4}\right)_{2} \mathrm{SO}_{4}$ [19].

2.2. Family $\mathrm{BaMF}_{4}(\mathrm{M}=\mathrm{Mg}, \mathrm{Mn}, \mathrm{Fe}, \mathrm{Co}, \mathrm{Ni}, \mathrm{Zn})$. - The $\mathrm{BaMF}_{4}$ fluorides are ferroelectric up to their melting temperature [4]. The value of the spontaneous polarization is close to $10 \mu \mathrm{C} \mathrm{cm}{ }^{-2}$ at $300 \mathrm{~K}$. The inversion of the polarization corresponds to a shift of the $\mathrm{Ba}^{2+}$ cation along the $c$-polar axis of the orthorhombic crystalline unit cell ( $\mathrm{mm} 2$ point group); it goes with the rotation of octahedra linked by corners leading to layers separated by the $\mathrm{Ba}^{2+}$ cations (Fig. 1).

These fluorides are bidimensional ferroelectrics.

2.3. FAmily $\mathrm{ABF}_{5}(\mathrm{~A}=\mathrm{Sr} ; \mathrm{B}=\mathrm{Al}, \mathrm{Cr}, \mathrm{Ga}$ And $\mathrm{A}=\mathrm{Ba} ; \mathrm{B}=\mathrm{Ti}, \mathrm{V}, \mathrm{Fe})$. - It is an analysis of the crystalline structure which made it possible to predict the ferroelectric properties of displacive type in $\operatorname{SrAlF}_{5}\left(\mathrm{~T}_{\mathrm{C}} \sim 700 \mathrm{~K}\right)$ Physical studies on crystal have shown the existence of piezoelectric and second harmonic generation properties. Two solid solutıons of $\mathrm{BaFe}_{1-x} \mathrm{In}_{x} \mathrm{~F}_{5}$ and $\mathrm{Ba}_{1-x} \mathrm{Sr}_{x} \mathrm{FeF}_{5}$ compositıons have shown that the value of $T_{\mathrm{C}}$ decreases with the size increase of the cation in 6 C.N. and with the size decrease of the alkaline-earth cation [6]. A similar result was obtained for perovskite phases derived from $\mathrm{BaTiO}_{3}$ (for example $\mathrm{BaTi}_{1-x} \mathrm{Zr}_{x} \mathrm{O}_{3}$ and $\left.\mathrm{Ba}_{1-x} \mathrm{Sr}_{x} \mathrm{TiO}_{3}\right)$ : this result is correlated with steric and bond covalency effets [20].

2.4. FAMILY $\mathrm{Na}_{2} \mathrm{MgAlF}_{7}$. - Second harmonic generation studies performed at $300 \mathrm{~K}$ made it possible to confirm the polar point group $4 \mathrm{~mm}$ for $\mathrm{Na}_{2} \mathrm{MgAlF}_{7}$ and $\mathrm{Na}_{2} \mathrm{NiMF}_{7}(\mathrm{M}=\mathrm{Al}, \mathrm{Fe}$ ) The phase transition temperature varies with composition; it takes place at $T>725 \mathrm{~K}[7]$.

2.5. FAMILY $\mathrm{K}_{3} \mathrm{Fe}_{5} \mathrm{~F}_{15}$. - Coupled ferroelectric and ferroelastic properties were predicted from atomic positions of $\mathrm{K}_{3} \mathrm{Fe}_{5} \mathrm{~F}_{15}$. The crystalline network of "tetragonal tungsten bronze" type shows an orthorhombic distortion at $300 \mathrm{~K}$. The Curie temperature $\left(T_{\mathrm{C}} \sim 490 \mathrm{~K}\right)$ was determined by calorimetric and dielectric measurements, and also by the disappearance of the ferroelastic domain structure under polarized light microscope [8]! The composition $\mathrm{K}_{3} \mathrm{Fe}_{5} \mathrm{~F}_{15}$ 


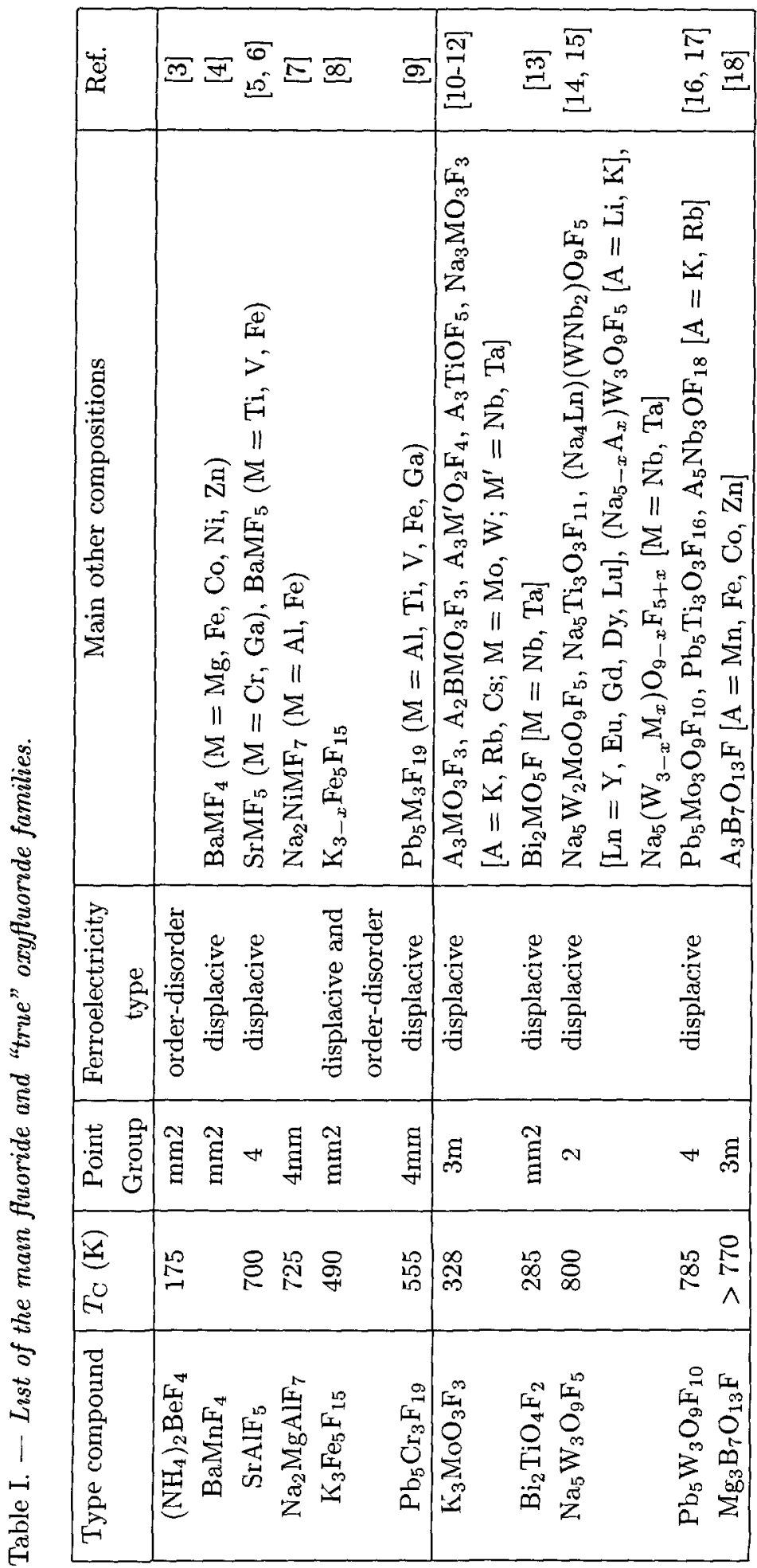




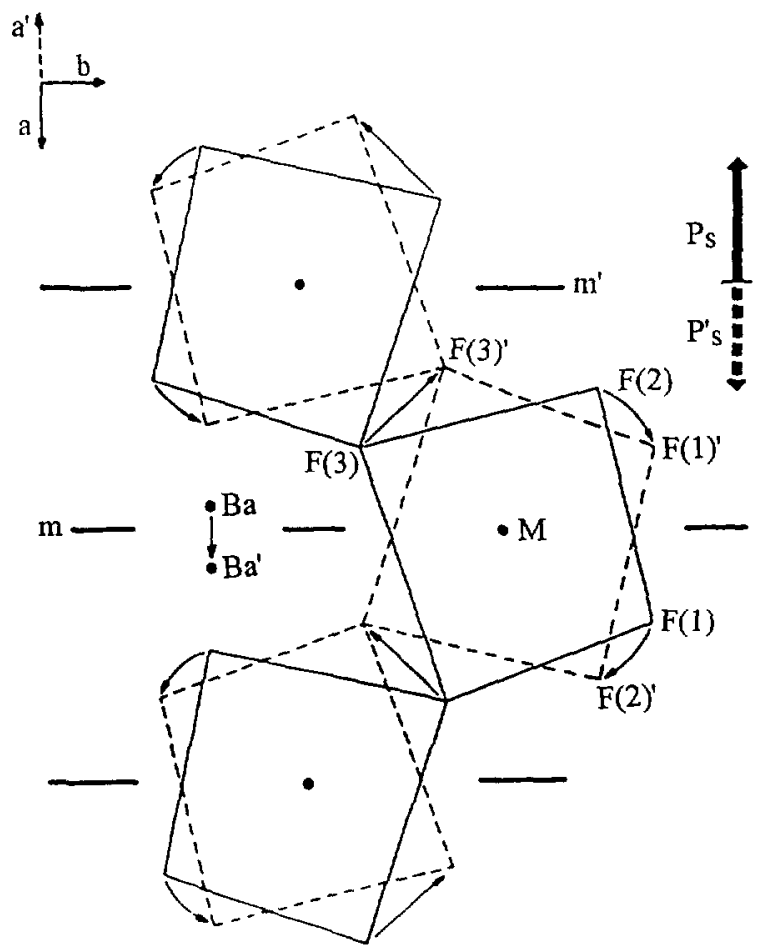

Fig. 1. - Atomic arrangement for the two polarities of $\mathrm{BaMF}_{4}$.

implies the simultaneous presence of $\mathrm{Fe}^{2+}$ and $\mathrm{Fe}^{3+}$ cations. The spontaneous polarization origin is correlated with the displacements along the polar axis of $\mathrm{Fe}^{2+}$ and $\mathrm{Fe}^{3+}$ cations in their actahedral sites, these cations being ordered in the crystalline network. Above $T_{\mathrm{C}}$, the iron atoms are localised at the octahedron center and $\mathrm{Fe}^{2+}$ and $\mathrm{Fe}^{3+}$ cations are disordered in some crystallographic sites [21]. This ferroelectric fluoride is thus both displacive and of the order-disorder type. So, it is different from oxides (for example $\mathrm{Ba}_{2} \mathrm{NaNb}_{5} \mathrm{O}_{15}, \mathrm{~Pb}_{2} \mathrm{Nb}_{5} \mathrm{O}_{15}$ ) of displacive type for which it is not isomorphous. Moreover, as will be mentioned in the oxyfluoride section, a low rate of $\mathrm{F}$-O substitution leads to the disappearance of the ferroelectric properties. The solid solution $\mathrm{K}_{3-x} \mathrm{Fe}_{5} \mathrm{~F}_{15}(0 \leq x \leq 1)$ also leads to the disappearance of the spontaneous polarization, the $\mathrm{K}^{+}$defect involves a change of the $\mathrm{Fe}^{2+} / \mathrm{Fe}^{3+}$ ratio which is not favourable to the creation of an order between the two cations [22].

2.6. FAMILY $\mathrm{Pb}_{5} \mathrm{Cr}_{3} \mathrm{~F}_{19}$. - Examination of the atomic positions of the polar crystalline network (4mm point group) of $\mathrm{Pb}_{5} \mathrm{Cr}_{3} \mathrm{~F}_{19}$ shows the $\mathrm{Cr}^{3+}$ cation to be off center from its octahedral site [9]. The ferroelectric-paraelectric transition at $T_{\mathrm{C}}=555 \mathrm{~K}$ is of first order type, in particular the birefringence sign changes abruptly at $T_{\mathrm{C}}$ (Fig. 2) [23]. The value of $T_{\mathrm{C}}$ varies with the $\mathrm{M}^{3+}$ cation size in the series of isomorphous compounds $\mathrm{Pb}_{5} \mathrm{M}_{3} \mathrm{~F}_{19}(\mathrm{M}=\mathrm{Al}, \mathrm{Ti}$, $\mathrm{V}, \mathrm{Cr}, \mathrm{Fe}, \mathrm{Ga}$ ) of displacive type [24]. The $\mathrm{Pb}_{5} \mathrm{Al}_{3} \mathrm{~F}_{19}$ compound shows a transition sequence very rich in ferroic properties [25]:

$$
\begin{array}{llll}
\mathrm{V}(4 \mathrm{~mm}) \rightarrow & \mathrm{IV}(4 / \mathrm{m}) \rightarrow & \mathrm{III}(2 / \mathrm{m}) \rightarrow & \mathrm{II}(4 / \mathrm{m}) \rightarrow \\
\text { ferroelectric } & \text { antiferroelectric } & \text { ferroelastic } & \text { paraelastic }(4 / \mathrm{mmm}) \\
\text { prototype } & \text { paraelectric }
\end{array}
$$




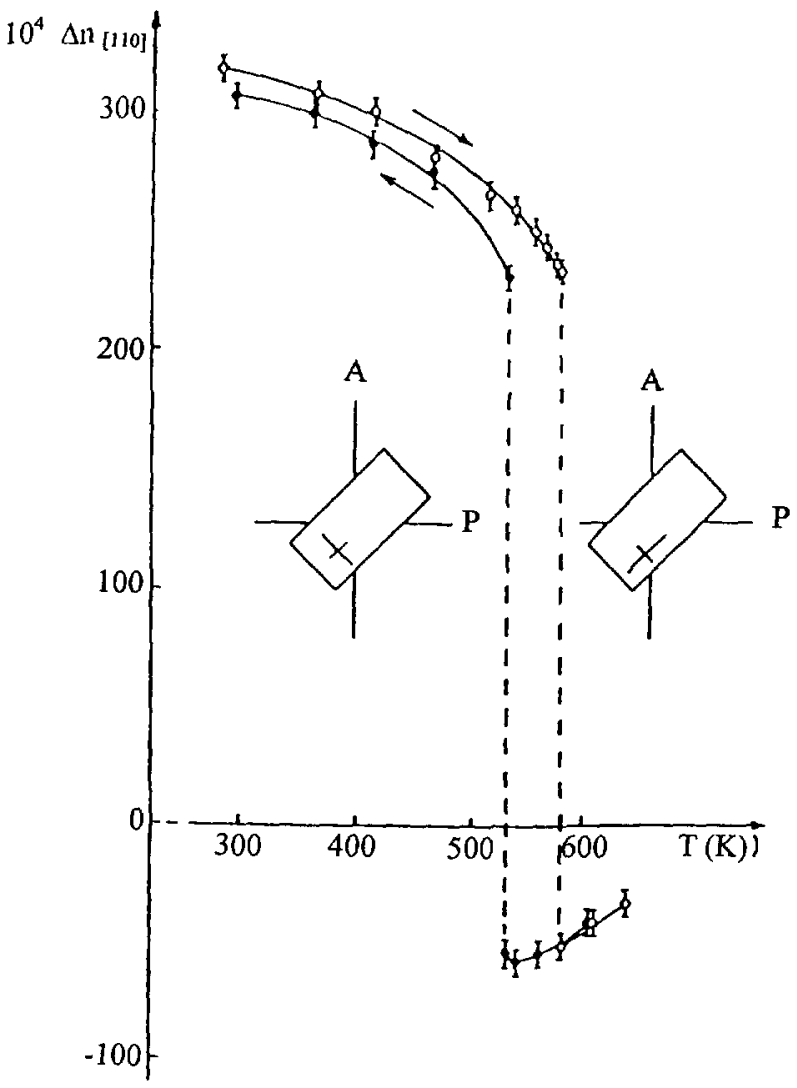

Fig. 2. - Temperature dependence of the birefringence for a $\mathrm{Pb}_{5} \mathrm{Cr}_{3} \mathrm{~F}_{19}$ crystal.

A pyroelectric current and a piezoelectric resonance have been shown in phase $\mathrm{V}$ [26]. Ferroelastic domains have been observed for phase III; the spontaneous strain appears abruptly on heating at the IV-III transition; it decreases then progressively and cancels at the III-II transition [27]. Figures 3 and 4 show a projection of the unit cell on $x \mathrm{O} y$ plane and the shift of $\mathrm{Al}^{3+}$ cations in the octahedra forming chains which develop along the polar axis.

The various distortions which appear in $\mathrm{Pb}_{5} \mathrm{Al}_{3} \mathrm{~F}_{19}$ result from the association of both the $6(\mathrm{sp})^{2}$ lone pair of $\mathrm{Pb}^{2+}$ cation and the small size of the $\mathrm{Al}^{3+}$ ion.

\section{3. "True" Ferroelectric Oxyfluorides}

3.1. FAMILY $\mathrm{K}_{3} \mathrm{MoO}_{3} \mathrm{~F}_{3}$. - Numerous $\mathrm{A}_{2} \mathrm{BMO}_{3} \mathrm{~F}_{3}\left(\mathrm{~A}, \mathrm{~B}=\mathrm{K}, \mathrm{Rb}\right.$, Cs with $r_{\mathrm{A}^{+}}>r_{\mathrm{B}^{+}}$ and $\mathrm{M}=\mathrm{Mo}, \mathrm{W}$ ) show a crystallographic distortion of the prototype cubic phase (m3m) of $\left(\mathrm{NH}_{4}\right)_{3} \mathrm{FeF}_{6}$ type. The ferroelectric properties which appear below $T_{\mathrm{C}}$ are coupled with ferroelastic properties. Physical studies on a $\mathrm{K}_{3} \mathrm{MoO}_{3} \mathrm{~F}_{3}$ crystal make it possible to visualize ferroelastic domains and to obtain both a P-E hysteresis loop and a pyroelectric current [28]. The value of $T_{\mathrm{C}}$ decreases when $M o$ is replaced by $W$, but is much more sensitive to the $\mathrm{B}^{+}$cation nature in the 6 C.N. site: the order which appears when $\mathrm{B}^{+}$is smaller than $\mathrm{A}^{+}$ localized in the 12 C.N. site, leads to a decrease in both the octahedron distortion and the 


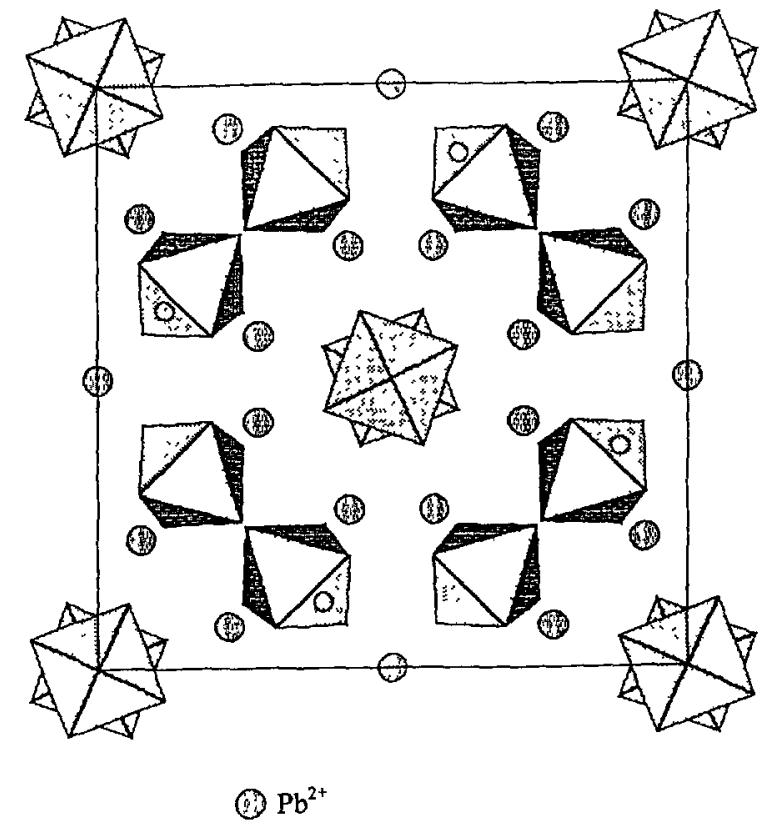

Fig. 3. - Crystallographic unit cell projection of the phase $\mathrm{V}$ of $\mathrm{Pb}_{5} \mathrm{Al}_{3} \mathrm{~F}_{19}$ along [001].

\begin{tabular}{|c|c|c|c|}
\hline phase $\mathrm{V}$ & phase IV (2V) & phase III & phase II \\
\hline & &
\end{tabular}

Fig. 4. - Schematic shift of $\mathrm{Al}^{3+}$ cations along the (001) axis for the $\mathrm{Pb}_{5} \mathrm{Al}_{3} \mathrm{~F}_{19}$ various phases.

value of $T_{\mathrm{C}}$ (as an example, $T_{\mathrm{C}}\left(\mathrm{Rb}_{3} \mathrm{MoO}_{3} \mathrm{~F}_{3}\right)=538 \mathrm{~K}$ and $T_{\mathrm{C}}\left(\mathrm{Rb}_{2} \mathrm{KMoO}_{3} \mathrm{~F}_{3}\right)=328 \mathrm{~K}$ ) $[10,11,29]$. All ions of the ferroelectric phase are displaced from their ideal positions in the prototype phase. Amplitudes and directions of atomic displacements show the crystal to be a tridimensional ferroelectric. Such a result is in good agreement with the small value of the

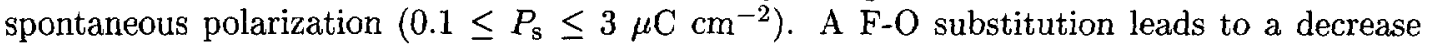
in $T_{C}$ [30]. Nine other compounds belong to this family, having the compositions $\mathrm{A}_{3} \mathrm{TiOF}_{5}$ and $\mathrm{A}_{3} \mathrm{MO}_{2} \mathrm{~F}_{4}(\mathrm{~A}=\mathrm{K}, \mathrm{Rb}, \mathrm{Cs} ; \mathrm{M}=\mathrm{Nb}, \mathrm{Ta})$. They are also ferroelectric-ferroelastic and generate second harmonics [31]. Recent studies also showed ferroelectric properties for the compounds $\mathrm{Na}_{3} \mathrm{MO}_{3} \mathrm{~F}_{3}(\mathrm{M}=\mathrm{Mo}, \mathrm{W})\left(T_{\mathrm{C}} \sim 805 \mathrm{~K}\right)$; the harmonic yield in nonlinear optics is here relatively strong $\left(R_{\mathrm{h}} / R_{\mathrm{h}}\right.$ (quartz) $\sim 40$ at room temperature) $[12,32]$. 


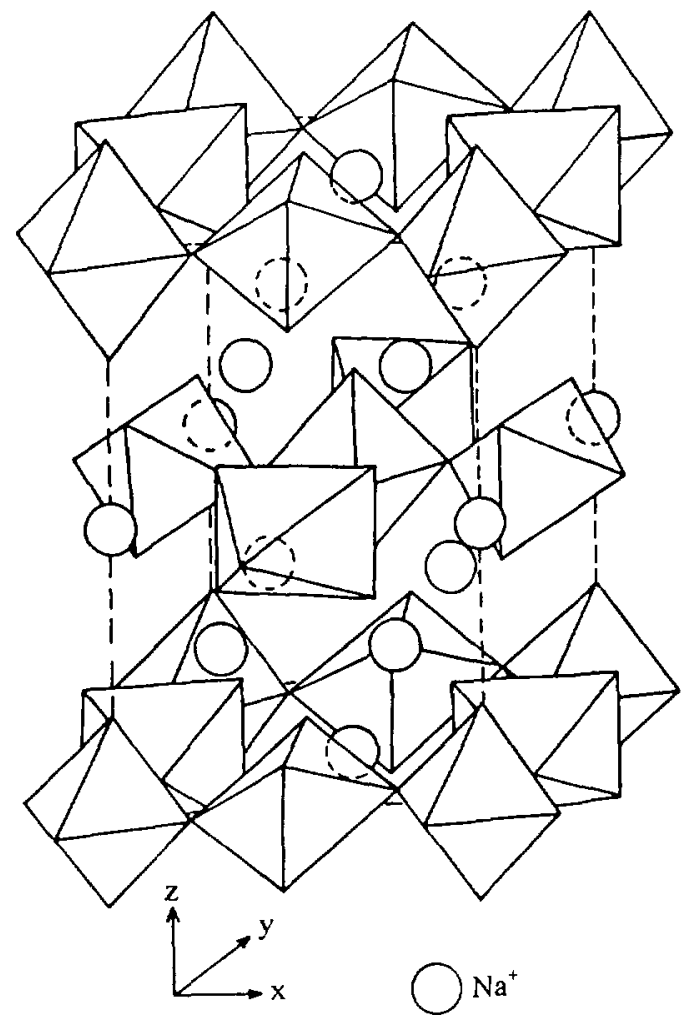

Fig. 5. - Schematic view of the $\mathrm{Na}_{5} \mathrm{Al}_{3} \mathrm{~F}_{14}$ structure.

3.2. FAMILY $\mathrm{Bi}_{2} \mathrm{TiO}_{4} \mathrm{~F}_{2}$. - The three compounds $\mathrm{Bi}_{2} \mathrm{~T}_{1} \mathrm{O}_{4} \mathrm{~F}_{2}$ and $\mathrm{Bi}_{2} \mathrm{MO}_{5} \mathrm{~F}(\mathrm{M}=\mathrm{Nb}, \mathrm{Ta})$ have only one perovskite layer in a crystalline network of "Aurivillius phase" type. They show a ferroelectric-paraelectric (mm2-4/mmm) transition [13]. A P-E hysteresis loop has been visualized. The close values of $T_{\mathrm{C}}\left(283 \leq T_{\mathrm{C}} \leq 303 \mathrm{~K}\right)$ confirm that $T_{\mathrm{C}}$ is mainly influenced by the polarizability of $\mathrm{A}^{n+}$ cations and by the number of perovskite layers in the family of composition $\mathrm{A}_{m-p+1} \mathrm{Bi}_{p-2} \mathrm{~B}_{m}(\mathrm{O}, \mathrm{F})_{3 m+1}$.

3.3. FAMILY $\mathrm{Na}_{5} \mathrm{~W}_{3} \mathrm{O}_{9} \mathrm{~F}_{5}$. - The compound $\mathrm{Na}_{5} \mathrm{~W}_{3} \mathrm{O}_{9} \mathrm{~F}_{5}$ with crystalline structure derived from that of the chiolite $\mathrm{Na}_{5} \mathrm{Al}_{3} \mathrm{~F}_{14}$ (Fig. 5) generates a second harmonic and shows coupled ferroelectric-ferroelastic properties $[14,33]$. Ferroelastic domains have been observed on crystal under polarized light microscope (Fig. 6). A detwinning of the crystal was obtained by application of an external mechanical stress leading to an increase in the pyroelectric coefficient as expected when the two ferroic properties are coupled. A strong maximum of the permittivity occurs at $T_{\mathrm{C}}$ (Fig. 7). The temperature dependence of the atomic positions showed the appearance of the spontaneous polarization, for $T<T_{\mathrm{C}}$, to be related to rotations of $\mathrm{W}(\mathrm{O}, \mathrm{F})_{6}$ octahedra around the $a$ and $b$ axes of the prototype tetragonal phase (4/mmm) [34]. Two other transitions occur in the ferroelectric region of $\mathrm{Na}_{5} \mathrm{~W}_{3} \mathrm{O}_{9} \mathrm{~F}_{5}$. Various substitutions (Mo, $\mathrm{Ti}, \mathrm{Nb}, \mathrm{Ta}$ to $\mathrm{W} ; \mathrm{Li}, \mathrm{K}$ to $\mathrm{Na}$; fluorine-oxygen) lead to a very rich family [35]. The value of $T_{\mathrm{C}}$ varies with the size of the cations and with the bond $\mathrm{M}-\mathrm{X}(\mathrm{X}=\mathrm{O}, \mathrm{F})$ covalency. The partial substitution of $\mathrm{Li}^{+}$to $\mathrm{Na}^{+}$made it possible to obtain crystals of very good optical quality and large size $\left(\sim 2 \mathrm{~cm}^{3}\right)$. 


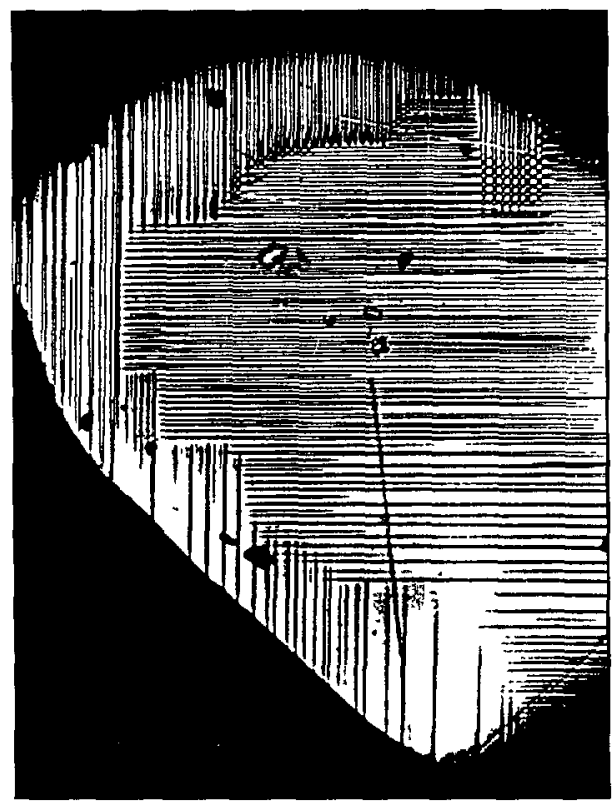

Fig 6. - Ferroelastic domains of $\mathrm{Na}_{5} \mathrm{~W}_{3} \mathrm{O}_{9} \mathrm{~F}_{5}$.

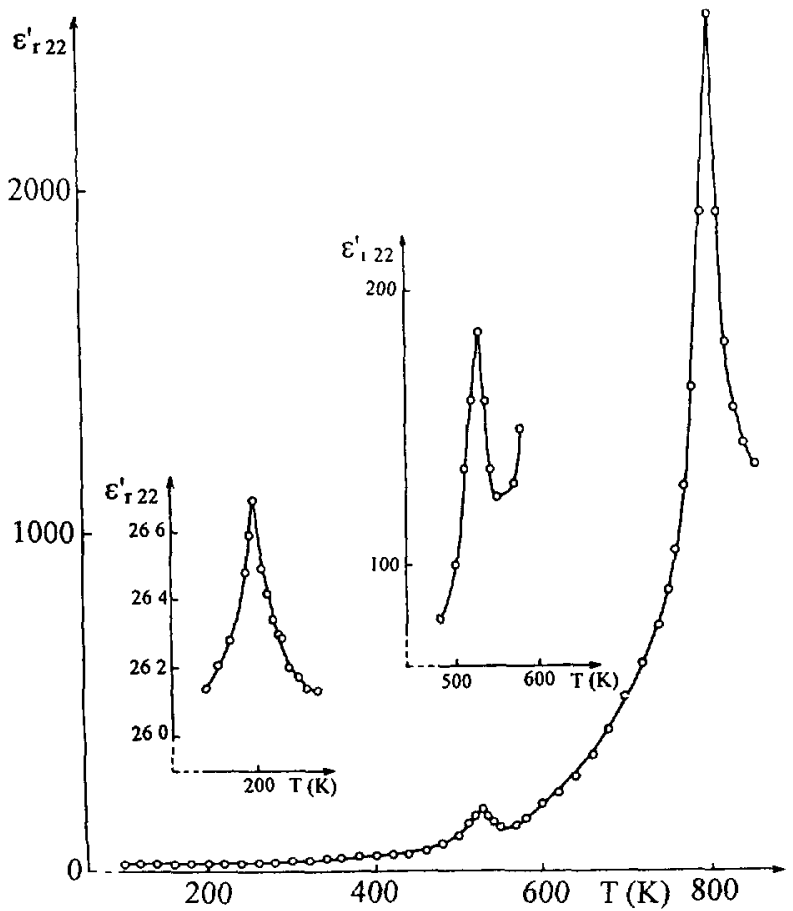

Fig. $7-$ Temperature dependence of the permuttivity for a $\mathrm{Na}_{5} \mathrm{~W}_{3} \mathrm{O}_{9} \mathrm{~F}_{5}$ crystal 
3.4. FAMILY $\mathrm{Pb}_{5} \mathrm{~W}_{3} \mathrm{O}_{9} \mathrm{~F}_{10}$. - Ferroelectric properties were predicted from the atomic arrangement of $\mathrm{Pb}_{5} \mathrm{~W}_{3} \mathrm{O}_{9} \mathrm{~F}_{10}$ which derives from that of $\mathrm{Pb}_{5} \mathrm{Cr}_{3} \mathrm{~F}_{19}$. The possibility of reversing the spontaneous polarization, characteristic dielectric properties and second harmonic generation led to confirming such an hypothesis [36]. The Curie temperature $\left(T_{\mathrm{C}}=785 \mathrm{~K}\right)$ corresponds to a ferroelectric (I4)-paraelectric (I $\overline{4})$ transition. Two isotypic phases have the same properties $\mathrm{Pb}_{5} \mathrm{Mo}_{3} \mathrm{O}_{9} \mathrm{~F}_{10}$ and $\mathrm{Pb}_{5} \mathrm{Ti}_{3} \mathrm{O}_{3} \mathrm{~F}_{16}$ [16].

Crystals of size $1.5 \times 1.5 \times 5 \mathrm{~mm}^{3}$, of composition $\mathrm{A}_{5} \mathrm{Nb}_{3} \mathrm{OF}_{18}(\mathrm{~A}=\mathrm{K}, \mathrm{Rb})$ and of crystalline structure close to that of $\mathrm{Pb}_{5} \mathrm{~W}_{3} \mathrm{O}_{9} \mathrm{~F}_{10}$ were obtained by slow cooling after dissolving in a $\mathrm{HF}$ solution. A piezoelectric resonance and a pyroelectric current were observed between 300 and $500 \mathrm{~K}[17]$.

\section{Oxyfluorides Derived from Ferroelectric Oxides}

4.1. Perovskite, Tetragonal Tungsten Bronze and Pyrochlore Types. - Oxygenated phases of perovskite, tetragonal tungsten bronze and pyrochlore type have ferroelectric properties. Their crystalline network shows octahedra linked by corners. The fluorine-oxygen substitution associated with a cationic substitution to ensure electric neutrality gives rise to a decrease in the Curie temperature, the spontaneous polarization and the harmonic yield in nonlinear optics. The decrease in $T_{\mathrm{C}}$ may be very abrupt even for low substitution rates. Figure 8 shows, as an example, that the replacement of only one oxygen on $60(0.25 / 15)$ leads to a decreasing in $T_{\mathrm{C}}$ of about $600 \mathrm{~K}$. Figure 9 shows clearly the decrease in $T_{\mathrm{C}}$ for such materials compared to true oxyfluoride ferroelectric [37]. The distortion of the $\mathrm{MX}_{6}(\mathrm{X}=\mathrm{O}, \mathrm{F})$ octahedra related to the displacement of the $\mathrm{M}^{n+}$ cation out of the octahedron center is responsible for ferroelectricity. When fluorine replaces oxygen, the $\mathrm{M}-\mathrm{X}$ bonds become less covalent, and the anisotropy decreases. So the increase in temperature up to $T_{\mathrm{C}}$ leading to more isotropic bonds (paraelectric phase) decreases.

When other transitions exist in the ferroelectric region, their temperature does not necessarily decrease when the amount of fluorine increases. Figure 10 shows the case of the solid solution $\mathrm{Ba}\left(\mathrm{Ti}_{1-x} \mathrm{Li}_{x}\right) \mathrm{O}_{3-3 x} \mathrm{~F}_{3 x}$ for which $T_{1}$ (orthorhombic-tetragonal transition) decreases and $T_{2}$ (rhomboedral-orthorhombic transition) increases. This system is very attractive. In fact, for composition $0 \leq x \lesssim 0.03$, the behavior is of classical ferroelectric type as for $\mathrm{BaTiO}_{3}$. On the contrary for $0.03<x \lesssim 0.15$, it is of relaxor type: when the frequency increases, the temperature $T_{\mathrm{m}}$ of $\epsilon_{\mathrm{r}}^{\prime \prime}(\mathrm{max})$ increases, the value of $\epsilon_{\mathrm{r}}^{\prime}$ decreases progressively and $\epsilon_{\mathrm{r}}^{\prime \prime}$ remains relatively constant, its value being relatively strong $\left(\epsilon_{\mathrm{r}}^{\prime \prime} \sim 100\right.$ at $\left.10^{4} \mathrm{~Hz}\right)$ for $T<T_{\mathrm{m}}[38,39]$. In addition, they show a microwave relaxation whose origin is related to 6 C.N. cation motions, along correlation chain in a double well potential model [40].

4.2. $\mathrm{LiTaO}_{3}$ TYPE. - Oxyfluorides of the $\mathrm{LiTaO}_{3}$ type have been obtained in $\mathrm{LiNbO}_{3}-\mathrm{LiF}-$ $\mathrm{NbO}_{2} \mathrm{~F}, \mathrm{LiTaO}_{3}-\mathrm{LiF}-\mathrm{TaO}_{2} \mathrm{~F}$ and $\mathrm{LiMO}_{3}-\mathrm{LiMgF}_{3}$ " ( $\left.\mathrm{M}=\mathrm{Nb}, \mathrm{Ta}\right)$ systems. The crystalline network is composed of octahedra linked by faces in the polar direction and by edges in other directions. The variation of $T_{\mathrm{C}}$ is correlated to the variation of the covalency degree of the $\mathrm{M}-\mathrm{X}$ $(\mathrm{X}=\mathrm{O}, \mathrm{F})$ bonds, and to the cationic non stoichiometry $[41,42]$. The fluoride $\mathrm{MgLiF}_{3}$ used as sintering additive is of great interest for densifying $\mathrm{LiTaO}_{3}$ ceramics at low temperature (Fig. 10) [43].

4.3. $\mathrm{Pb}_{5} \mathrm{Ge}_{3} \mathrm{O}_{11}$ TYPE. - The replacement of oxygen by fluorine goes with the creation of defects in the site of $\mathrm{Pb}^{2+}:\left(\mathrm{Pb}_{1-x / 2} \square_{x / 2}\right)_{5} \mathrm{Ge}_{3} \mathrm{O}_{11-5 x} \mathrm{~F}_{5 x}(0 \leq x<0.10)$. The Curie temperature decreases with $x$ from 453 to $355 \mathrm{~K}$ [44]. 


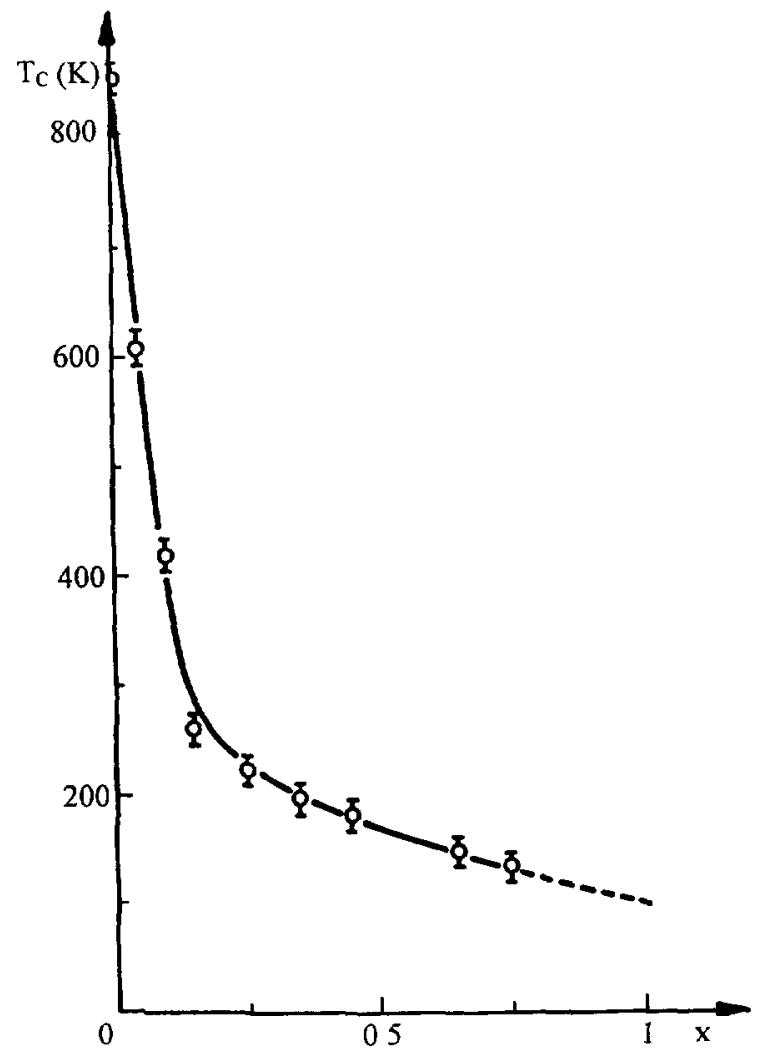

Fig. 8. - Variation of $T_{\mathrm{C}}$ with $x$ for ceramics of composition $\mathrm{Ba}_{2-x} \mathrm{Na}_{x} \mathrm{Nb}_{5} \mathrm{O}_{15-x} \mathrm{~F}_{x}$

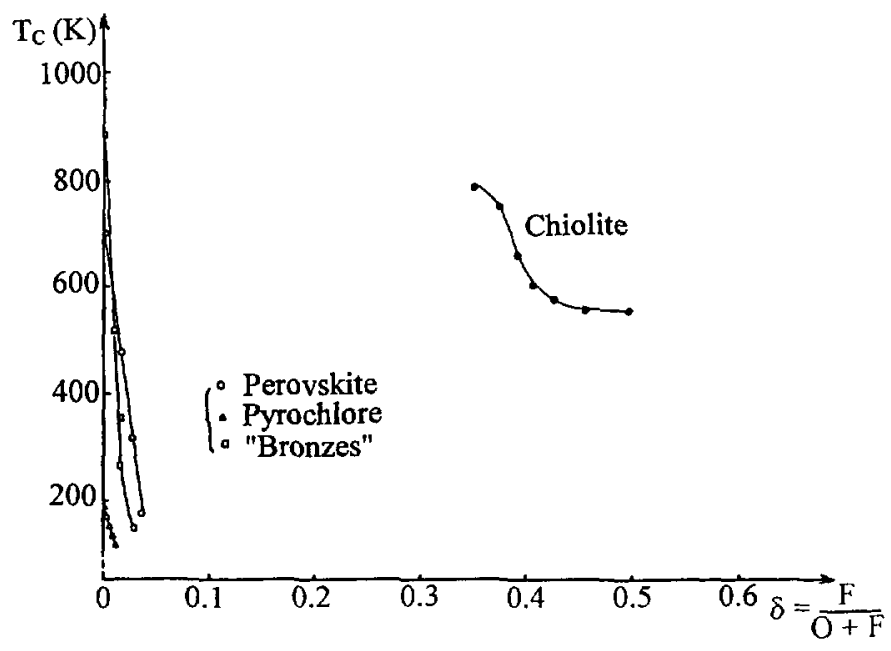

Fig. 9. - Variation of $T_{\mathrm{C}}$ with the rate of F-O substitution for a true oxyfluoride ferroelectric and for oxyfluorides derived from ferroelectric oxides 


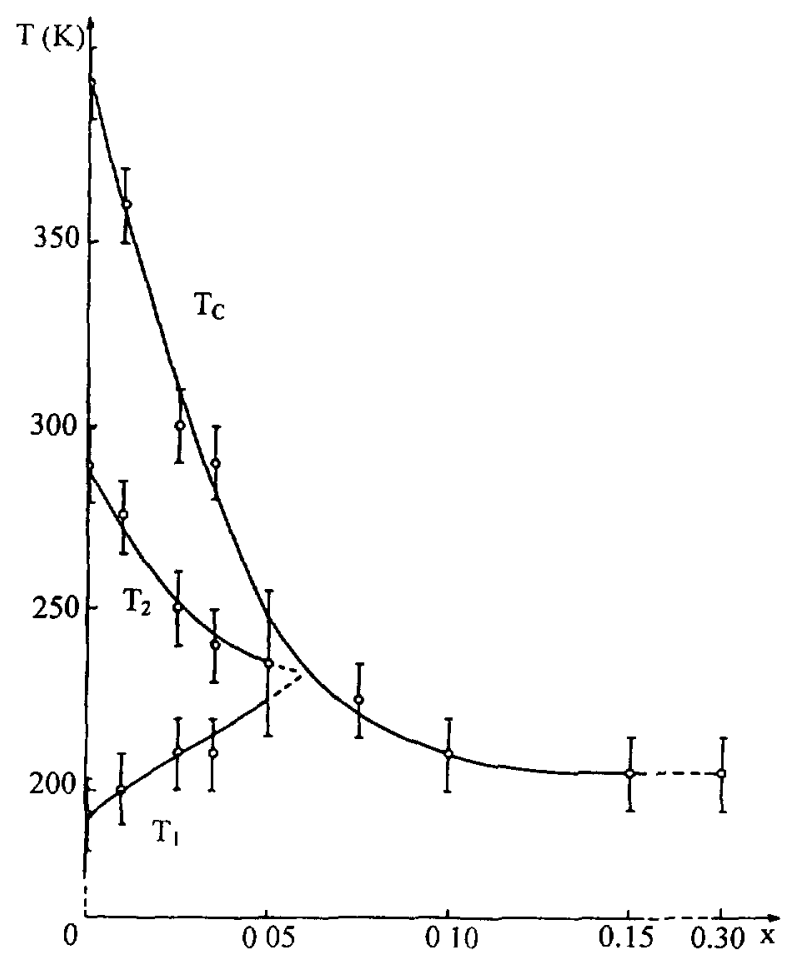

Fig. 10. - Varıation of the transition temperature with $x$ for ceramics with composition $\mathrm{Ba}\left(\mathrm{Ti}_{1-x} \mathrm{Li}_{x}\right) \mathrm{O}_{3-3 x} \mathrm{~F}_{3 x}$.

4.4. $\left(\mathrm{NH}_{4}\right)_{2} \mathrm{SO}_{4}$ TYPE. - The two solid solutions of compositions $\left(\mathrm{NH}_{4}\right)_{2}\left(\mathrm{SO}_{4}\right)_{1-x}(\mathrm{BeF})_{x}$ $(0 \leq x \leq 0.22 ; 0.70 \leq x \leq 1)$ derive from the two ferroelectric compounds $\left(\mathrm{NH}_{4}\right)_{2} \mathrm{SO}_{4}$ $\left(T_{\mathrm{C}}=223 \mathrm{~K}\right)$ and $\left(\mathrm{NH}_{4}\right)_{2} \mathrm{BeF}_{4}\left(T_{\mathrm{C}}=175 \mathrm{~K}\right)$. The Curie temperature decreases when the composition deviates from one or the other of the limit phases [19].

4.5. $\mathrm{BaAl}_{2} \mathrm{O}_{4}$ TYPE. - Non-linear properties have been detected in crystals and ceramics of $\left(\mathrm{Ba}_{1-x} \mathrm{~A}_{x}\right)\left(\mathrm{Al}_{2-2 x} \mathrm{Li}_{2 x}\right) \mathrm{O}_{4-4 x} \mathrm{~F}_{4 x}(\mathrm{~A}=\mathrm{Sr}, \mathrm{Ba}, \mathrm{Pb})(0 \leq x \leq 0.30)$ compositions. The Curie temperature varies from 240 to $426 \mathrm{~K}$, the spontaneous polarization from 8 to $15 \mu \mathrm{C} \mathrm{cm}^{-2}$ and the coercive field from 5 to $2 \times 10^{6} \mathrm{~V} \mathrm{~m}^{-1}$. Although having a spontaneous polarization, these materials are in fact structurally ferrielectric [45-47].

4.6. Simultaneous Fluorine-Oxygen and Lead-Alcaline Earth Substitutions. The F-O substitution generally leads to a decrease in $T_{\mathrm{C}}$. Moreover, the $\mathrm{Pb}^{2+}-\mathrm{A}^{2+}(\mathrm{A}=\mathrm{Sr}$, $\mathrm{Ba}$ ) substitution in oxidized titanates, for an example, leads to an increase in $T_{\mathrm{C}}$ in correlation with the strong distortion created by the $6(\mathrm{sp})^{2}$ lone pair of the $\mathrm{Pb}^{2+}$ cation. When $\mathrm{F}^{-}$and $\mathrm{Pb}^{2+}$ ions are introduced together into the crystalline network, two competitive effects appear. The anionic substitution firstly causes a decrease in $T_{\mathrm{C}}$ followed by an increase in $T_{\mathrm{C}}$, thus giving a minimum of $T_{\mathrm{C}}$ for a definite composition (Fig. 11 for example) [47]. 


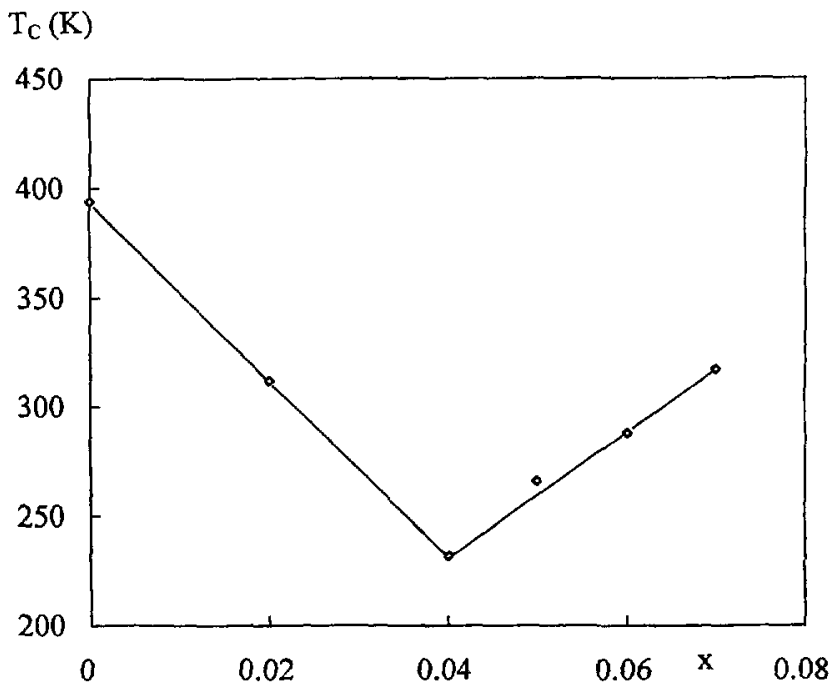

Fig. 11. - Variation of $T_{\mathrm{C}}$ with $x$ for ceramics with composition $\mathrm{Ba}_{1-x} \mathrm{~Pb}_{x}\left(\mathrm{Al}_{2-2 x} \mathrm{Ll}_{2 x}\right) \mathrm{O}_{4-4 x} \mathrm{~F}_{4 x}$.

\section{Some Potential Applications}

5.1. Dielectrics for Type I Capacitors. - The decrease in the Curie temperature by F-O substitutions may make it possible to situate the paraelectric phase in the usual temperature range for applications $(250$ to $350 \mathrm{~K}$ ). In this temperature domain, the still high values of the permittivity $\epsilon_{\mathrm{r}}^{\prime}$ and its stability in frequency mean that such materials are of potential interest as dielectrics for type I capacitors. For example, let us consider the values of the following pyrochlore oxyfluoride $\mathrm{Pb}_{180} \mathrm{Zn}_{015} \mathrm{Na}_{0}{ }_{05} \mathrm{O}_{69} \mathrm{~F}_{005}\left(\epsilon_{\mathrm{r}}^{\prime} \sim 200\right.$; $\left.\tan \delta \sim 3 \times 10^{-4}\right)$ [48]. Thick films have been prepared by serigraphy; the permittivity is very stable $\left(\epsilon_{\mathrm{r}}^{\prime} \sim 80\right.$ from $10^{3}$ to $10^{6} \mathrm{~Hz}$ ) and the dielectric losses are very low $\left(\tan \delta<10^{-3}\right)$ [49]. Thin films have also been obtained by cathodic sputtering, but the amorphous character of the films causes a decrease in permittivity $\left(\epsilon_{\mathrm{r}}^{\prime} \sim 30\right)[50]$.

5.2. Dielectrics for Type II Capacitors. - The replacement of palladium for electrodes by cheaper metals or alloys requires the use of dielectrics with a low sintering temperature. We give the two following examples:

- The addition of $\mathrm{LiF}$ or $\mathrm{BaLiF}_{3}$ to $\mathrm{BaTiO}_{3}$ has made it possible to decrease the sintering temperature from 1400 to $930^{\circ} \mathrm{C}$. The decrease of $T_{\mathrm{C}}\left(\mathrm{BaTiO}_{3}\right)=393 \mathrm{~K}$ to a temperature close to $300 \mathrm{~K}$ leads to very good electric performances $\left(\epsilon_{\mathrm{r}}^{\prime}(300 \mathrm{~K})=8300 ; \tan \delta(300 \mathrm{~K})=\right.$ $\left.40 \times 10^{-4}\right)$. Multilayer capacitors of $3.20 \times 2.40 \times 1.15 \mathrm{~mm}^{3}$ dimensions have been made with such a dielectric: they reach a capacity of $162 \mathrm{nF}$ with Ag-Pd electrodes with a high concentration in silver $[51,52]$.

- The addition of $\mathrm{BaLiF}_{3}$ to $\mathrm{Pb}\left(\mathrm{Fe}_{1 / 2} \mathrm{Nb}_{1 / 2}\right) \mathrm{O}_{3}$ has made it possible to decrease the Curie temperature of the latter $\left(T_{\mathrm{C}}=387 \mathrm{~K}\right)$ to room temperature and to sinter ceramics at temperature lower than $900^{\circ} \mathrm{C}$. Figure 12 shows that the values of $\epsilon_{\mathrm{r}}^{\prime}$ are very strong; the thermal dependence of $\epsilon_{\mathrm{r}}^{\prime}$ means that such dielectrics may be put in the Z5U class [53]. 


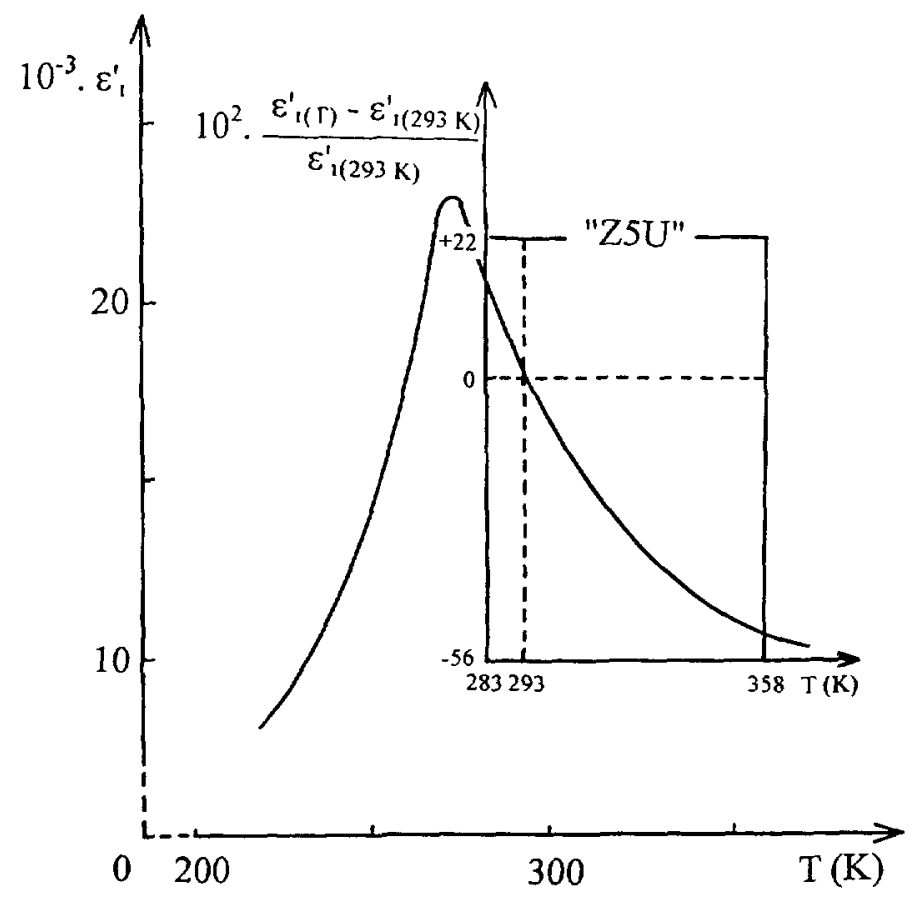

Fig. 12. - Temperature dependence of $\epsilon_{\mathrm{r}}^{\prime}$ for an oxyfluorıde ceramic derived from $\mathrm{Pb}\left(\mathrm{Fe}_{1 / 2} \mathrm{Nb}_{1 / 2}\right) \mathrm{O}_{3}$.

The addition of both $\mathrm{LiF}$ and $\mathrm{Li}_{2} \mathrm{CO}_{3}$ makes it possible to sinter ceramics of $\mathrm{Pb}\left(\mathrm{Mg}_{1 / 3} \mathrm{Nb}_{2 / 3}\right)$ $\mathrm{O}_{3}$ [PMN] at $850^{\circ} \mathrm{C}$ avoiding in addition the parasite formation of the pyrochlore phase [54].

5.3. Crystals for Electro-Optic Applications. - Crystal growth studies are in progress on ferroelectric fluorides with a view to electro-optic applications due in particular to the good transparency of fluoride crystals.

\section{Discussion - Conclusion}

Fluoride and oxyfluoride ferroelectrics constitute a group of new materials. Although the metalfluorine bonds lead to a strongly ionic character, their crystalline networks show distortions capable of leading to ferroelectrics of displacive or order-disorder type. The Curie temperature may be very high; for example, the phases of $\mathrm{BaMF}_{4}$ type are ferroelectric up to their melting temperature. There are now large families in which the value of $T_{\mathrm{C}}$ may be related to the size and the electronic configuration of the various cations, and to the $\mathrm{MX}(\mathrm{X}=\mathrm{O}, \mathrm{F})$ bond covalency. Ferroelectricity in fluorides and oxyfluorides has been predicted from very precise structural studies [55].

The following results are to be noted. The $\mathrm{Pb}_{5} \mathrm{Al}_{3} \mathrm{~F}_{19}$ compound has a very rich transition sequence with various ferroic properties: ferroelectricity, antiferroelectricity, ferroelasticity. The fluorine $\mathrm{K}_{3} \mathrm{Fe}_{5} \mathrm{~F}_{15}$ of "bronze" type constitutes a very original example. In fact, the corresponding oxides are ferroelectric and a low $\mathrm{F}-\mathrm{O}$ substitution rate $(\mathrm{F} / \mathrm{O} \sim 1 / 15$ ) generally causes the disappearance of the spontaneous polarization; the very distorted $\mathrm{MO}_{6}$ octahedra leads to non-distorted $\mathrm{M}(\mathrm{O}, \mathrm{F})_{6}$ ones, the $\mathrm{M}^{n+}$ cation being localized at the octahedron center. 
In the case of the $\mathrm{K}_{3} \mathrm{Fe}_{5} \mathrm{~F}_{15}$ fluoride, it is the simultaneous presence of $\mathrm{Fe}^{2+}$ and $\mathrm{Fe}^{3+}$ which leads to an ordered arrangement giving rise to local dipolar moments in octahedra and thus to a spontaneous polarization. This material fully deserves its "bronzes" designation as is the case for the $\mathrm{K}_{05}{ }_{57} \mathrm{WO}_{3}$ oxide type which also has tungsten in the two oxidized states $+\mathrm{V}$ and +VI. The oxyfluoride $\mathrm{Na}_{5} \mathrm{~W}_{3} \mathrm{O}_{9} \mathrm{~F}_{5}$ is the leading member of an important family of materials; their good quality and large crystals make them potential candidates for applications.

The progressive F-O substitution from ferroelectric oxides with octahedra linked by corners has the advantage for modulating the value of $T_{\mathrm{C}}$, and thus the value of the permittivity at the desired temperature; in addition, it makes it possible to densify ceramics at low temperature. Moreover, the good transparency of fluorides means that the corresponding crystals have a potential value for electro-optic applications.

\section{References}

[1] Ravez J., Non linear properties of fluorides, Inorg. Solld Fluorides, Acad Press (1985) 469

[2] Edwardson P.J., Boyer L.L, Newman R.L., Fox D.H., Hardy J.R., Flocken J.W., Guenther R.A. and Mei W., Ferroelectricity in perovskitelike $\mathrm{NaCaF}_{3}$ predicted ab inttio, Phys. Rev. $B 39$ (1989) 9738.

[3] Pepinsky R. and Jona F., New ferroelectric crystal containing no oxygen, Phys. Rev. 105 (1957) 344.

[4] Eibschütz M., Guggenheim H.G., Wemple S.H., Camlibel I. and DiDomenico M., Ferroelectricity in $\mathrm{BaM}^{2+} \mathrm{F}_{4}$, Phys Letters 29A (1969) 409.

[5] Abrahams S.C., Ravez J., Simon A. and Chaminade J.P., Ferroelectric behavior and phase transition at $715 \mathrm{~K}$ in $\mathrm{SrAlF}_{5}, J$. Appl. Phys. 52 (1981) 4740.

[6] Ravez J., Andriamampianina V., Simon A., Grannec J. and Abrahams S.C., Correlation between Curie temperature and cation radius in the ferroelectric $\mathrm{BaFeF}_{5}$ family, Ferroelectrics. 109 (1990) 33

[7] Tressaud A., Lozano L. and Ravez J., A cell for dielectric measurements in fluorinated atmospheres, J. Fluor. Chem. 19 (1981) 61.

[8] Ravez J., Abrahams S.C. and de Pape R., Ferroelectric-ferroelastic properties of $\mathrm{K}_{3} \mathrm{Fe}_{5} \mathrm{~F}_{15}$ and the phase transition at $490 \mathrm{~K}, J$. Appl. Phys. 65 (1989) 3987.

[9] Abrahams S.C., Albertsson J., Svensson C. and Ravez J., Structure of $\mathrm{Pb}_{5} \mathrm{Cr}_{3} \mathrm{~F}_{19}$ at $295 \mathrm{~K}$, polarization reversal and the $555 \mathrm{~K}$ phase transition, Acta Cryst. B 46 (1990) 497.

[10] Peraudeau G., Ravez J. et Arend H., Étude des transitions de phases des composés $\mathrm{Rb}_{2} \mathrm{KMO}_{3} \mathrm{~F}_{3}, \mathrm{Cs}_{2} \mathrm{KMO}_{3} \mathrm{~F}_{3}$ et $\mathrm{Cs}_{2} \mathrm{RbMO}_{3} \mathrm{~F}_{3}(\mathrm{M}=\mathrm{Mo}, \mathrm{W})$, Solvd State Commun. 27 (1978) 515.

[11] Peraudeau G., Ravez J., Hagenmuller P. and Arend H., Study of phase transition in $\mathrm{A}_{3} \mathrm{MO}_{3} \mathrm{~F}_{3}$ compounds $(\mathrm{A}=\mathrm{K}, \mathrm{Rb}, \mathrm{Cs} ; \mathrm{M}=\mathrm{Mo}, \mathrm{W})$, Solvd State Commun. 27 (1978) 591.

[12] Chaminade J.P., Cervera-Marzal M. and Ravez J., $\mathrm{Na}_{3} \mathrm{WO}_{3} \mathrm{~F}_{3}$ : a new ferroelasticferroelectric oxyfluoride, Mat. Sc. Engın. B 3 (1989) 497.

[13] Ismaïlzade I.H. and Ravez $\mathrm{J}_{\text {., }} \mathrm{Bi}_{2} \mathrm{TiO}_{4} \mathrm{~F}_{2}$. A new one-layer perovskite-like ferroelectric, Ferroelectrics 21 (1978) 423.

[14] Doumerc J.P., Elaatmani M., Ravez J., Pouchard M. et Hagenmuller P., Les transitions de phases de $\mathrm{Na}_{5} \mathrm{~W}_{3} \mathrm{O}_{9} \mathrm{~F}_{5}$, Solid State Commun. 32 (1979) 111.

[15] Ravez J., Elaatmani M. et Hagenmuller P., Influence de divers types de substitution sur les températures de transition des oxyfluorures ferroélectriques de type chiolite, Mat. Res. Bull. 16 (1981) 1253. 
[16] Arquis S., Ravez J., Chaminade J.P., Hagenmuller P , Abrahams S.C. and Marsh P., Phase transition and ferroelectric behavior in $\mathrm{Pb}_{5} \mathrm{M}_{3} \mathrm{O}_{9} \mathrm{~F}_{10}(\mathrm{M}=\mathrm{Mo}, \mathrm{W})$ and phase transition in $\mathrm{Pb}_{5} \mathrm{Ti}_{3} \mathrm{O}_{3} \mathrm{~F}_{16}$, J. Appl. Phys. 60 (1986) 357.

[17] Agulyansky A.I., Ravez J., von der Mühll R. and Simon A., Piezoelectricity and pyroelectricity in $\mathrm{A}_{5} \mathrm{Nb}_{3} \mathrm{OF}_{18}$, Ferroelectrucs 158 (1994) 139.

[18] Bither T.A. and Young H.S., Nitrato- and fluoboracites $\mathrm{M}_{3} \mathrm{~B}_{7} \mathrm{O}_{13} \mathrm{NO}_{3}$ and $\mathrm{M}_{3} \mathrm{~B}_{7} \mathrm{O}_{13} \mathrm{~F}$, J. Solvd State Chem. 10 (1974) 302.

[19] Hoshino S., Vedam K., Okaya Y. and Pepinsky R., Dielectric and thermal study of $\left(\mathrm{NH}_{4}\right)_{2} \mathrm{SO}_{4}$ and $\left(\mathrm{NH}_{4}\right)_{2} \mathrm{BeF}_{4}$ transitions, Phys. Rev. 112 (1958) 405.

[20] Ravez J., Pouchard M. and Hagenmuller P., Chemical bonding and ferroelectric perovskites, Eur. J. Solzd State Inorg. Chem. 28 (1991) 1107.

[21] Ravez J., Abrahams S.C., Simon A., Calage Y. and de Pape R., The first ferroelectric fluoride with a tungsten bronze-type structure, Ferroelectrics 108 (1990) 91.

[22] Ravez J., Abrahams S.C., Mercier A.M., Rabardel L. and de Pape R., Phase transition dependence on composition in ferroelectric-ferroelastic $K_{3-x} \mathrm{Fe}_{5} \mathrm{~F}_{15}$ for $0 \leq x \leq 0.20$, J. Appl. Phys. 67 (1990) 2681.

[23] Arquis S., Ravez J. and Abrahams S.C., Phase transition at $555 \mathrm{~K}$ in non linear optic $\mathrm{Pb}_{5} \mathrm{Cr}_{3} \mathrm{~F}_{19}$, J. Appl. Cryst. 19 (1986) 374.

[24] Ravez J., Andriamampianina V., Simon A., Grannec J. and Abrahams S.C., Ferroelectricparaelectric phase transition in $\mathrm{Pb}_{5} \mathrm{M}_{3} \mathrm{~F}_{19}$ with $\mathrm{M}=\mathrm{Al}, \mathrm{Ti}, \mathrm{V}, \mathrm{Cr}, \mathrm{Fe}, \mathrm{Ga}, J$. Appl. Phys. 70 (1991) 1331.

[25] Ravez J., Andriamampianina V. and Abrahams S.C., The ferroelectric, antiferroelectric, ferroelastic and paraelastic phases of $\mathrm{Pb}_{5} \mathrm{Al}_{3} \mathrm{~F}_{19}$, Ferroelectrics 158 (1994) 133.

[26] Sarraute S., Ravez J., von der Mühll R., Bravic G., Feigelson R.S. and Abrahams S.C., Structure of ferroelectric $\mathrm{Pb}_{5} \mathrm{Al}_{3} \mathrm{~F}_{19}$ at $160 \mathrm{~K}$, polarisation reversal and relationship to ferroelectric $\mathrm{Pb}_{5} \mathrm{Cr}_{3} \mathrm{~F}_{19}$, Acta Cryst. B 52 (1996) 72.

[27] Ravez J., La première phase monoclinique ferroélastique de type $\mathrm{A}_{5} \mathrm{M}_{3} \mathrm{X}_{19}, C . R$. Acad. Sc. 317 (1993) 589.

[28] Ye Z.G., Ravez J., Rivera J.P., Chaminade J.P. and Schmid H., Optical and dielectric studies of ferroelectric oxyfluoride $\mathrm{K}_{3} \mathrm{MoO}_{3} \mathrm{~F}_{3}$ single crystals, Ferroelectrics 124 (1991) 281.

[29] Ravez J., Peraudeau G., Arend H., Abrahams S.C. and Hagenmuller P., A new family of ferroelectric materials with composition $\mathrm{A}_{2} \mathrm{BMO}_{3} \mathrm{~F}_{3}\left(\mathrm{~A}, \mathrm{~B}=\mathrm{K}, \mathrm{Rb}, \mathrm{Cs}\right.$ for $r_{\mathrm{A}+} \geq r_{\mathrm{B}+}$ and $\mathrm{M}=\mathrm{Mo}, \mathrm{W}$ ), Ferroelectrics 26 (1980) 767.

[30] Lorient M., Tressaud A. et Ravez J., Les transitions de phases dans les systèmes $\mathrm{Rb}_{3} \mathrm{MoO}_{3} \mathrm{~F}_{3}-\mathrm{Rb}_{3} \mathrm{FeF} \mathrm{F}_{6}$ et $\left(\mathrm{NH}_{4}\right)_{3} \mathrm{FeF}_{6}-\mathrm{Rb}_{3} \mathrm{FeF} \mathrm{F}_{6}$, Rev. Chim. Miner. 19 (1982) 128.

[31] Fouad M., Chaminade J.P., Ravez J. et Hagenmuller P., Les transitions de phases des oxyfluorures $\mathrm{A}_{3} \mathrm{TiOF}_{5}$ et $\mathrm{A}_{3} \mathrm{MO}_{2} \mathrm{~F}_{4}(\mathrm{~A}=\mathrm{K}, \mathrm{Rb}, \mathrm{Cs} ; \mathrm{M}=\mathrm{Nb}, \mathrm{Ta})$, Rev. Chim. Miner. 24 (1987) 1.

[32] Chaminade J.P., Cervera-Marzal M., Ravez J. and Hagenmuller P., Ferroelastic and ferroelectric behavior of the oxyfluoride $\mathrm{Na}_{3} \mathrm{MoO}_{3} \mathrm{~F}_{3}$, Mat. Res. Bull. 21 (1986) 1209.

[33] Ravez J., Elaatmani M. et Chaminade J.P., Préparation, études optiques et diélectriques de monocristaux de $\mathrm{Na}_{5} \mathrm{~W}_{3} \mathrm{O}_{9} \mathrm{~F}_{5}$, Solvd State Commun. 32 (1979) 749.

[34] Ihringer J., Abrahams S.C., Prandl W., Ravez J. and Hewat A.W., Structural study of the $\mathrm{Na}_{5} \mathrm{~W}_{3} \mathrm{O}_{9} \mathrm{~F}_{5}$ phase transitions by $\mathrm{X}$-ray and neutron diffraction, Phase Transitıons 33 (1991) 69.

[35] Ravez J., Elaatmani M., Cervera-Marzal M., Chaminade J.P. et Pouchard M., Propriétés cristallographiques et diélectriques de deux nouvelles familles d'oxyfluorures contenant des ions $\mathrm{Li}^{+}$et $\mathrm{K}^{+}$et de structure dérivée du type chiolite, Mat. Res. Bull. 16 (1981) 1167. 
[36] Ravez J., Abrahams S.C., Marsh P., Arquis S and Chaminade J.P., Ferroelectric behavior and phase transition at $785 \mathrm{~K}$ in $\mathrm{Pb}_{5} \mathrm{~W}_{3} \mathrm{O}_{9} \mathrm{~F}_{10}$, Jpn. J. Appl. Phys. 24 (1985) 232.

[37] Ravez J., Les oxyfluorures ferroélectriques en 1986, Rev. Chim. 23 (1986) 460.

[38] Cross L.E., Relaxor ferroelectrics, Ferroelectrics 76 (1987) 241.

[39] Ravez J. et Simon A., Le premier relaxeur ferroélectrique oxyfluoré, Phys. Status Solvdr 159 (1997) 517.

[40] Elissalde C., Ravez J., Kazaoui S. and Etourneau J., High frequency dielectric relaxation in oxyfluoride perovskite ceramics, Mat. Sc. Engın. B 15 (1992) 192.

[41] Guelin J., Ravez J. et Hagenmuller P., Nouvelles phases oxyfluorées ferroélectriques nonstcechiométriques dérivées de $\mathrm{LiNbO}_{3}$ et de $\mathrm{LiTaO}_{3}$, J. Less Common Metals 137 (1988) 75.

[42] Ye Z.G., von der Mühll R. and Ravez J., New oxyfluorides and highly densified ceramics related to $\mathrm{LiNbO}_{3}, J$. Phys. Chem. Solids 50 (1989) 809.

[43] Ye Z.G., von der Mühll R. and Ravez J., Sintering mechanism of $\mathrm{LiTaO}_{3}$ ceramics by the addition of lithium and magnesium fluorides, Proc. IEEE Int. Symp. Appl. Ferroelectrics (1991) 566.

[44] Bush A.A. and Venevtsev Y.N., Growth and certain properties of $\mathrm{Pb}_{5} \mathrm{Ge}_{3}(\mathrm{O}, \mathrm{F})_{11}$ ferroelectric crystals, Inorg. Mat. 17 (1981) 216.

[45] Dune F.G. and Stemple N.R., Ferroelectric properties of $\mathrm{BaLl}_{2 x} \mathrm{Al}_{2-2 x} \mathrm{~F}_{4 x} \mathrm{O}_{4-4 x}$, Phys. Rev. 120 (1960) 1949.

[46] Huang S.Y., von der Muhll R., Ravez J. and Hagenmuller P., Investigation of ferroelectric and pyroelectric properties of ceramics with composition $\mathrm{Ba}\left(\mathrm{Li}_{2 x} \mathrm{Al}_{2-2 x}\right) \mathrm{O}_{4-4 x} \mathrm{~F}_{4 x}$ $(0 \leq x \leq 0.3)$, Proc. IEEE Int. Symp. Appl. Ferroelectrics (1992) 123.

[47] Huang S.Y., von der Mihll R., Ravez J. and Hagenmuller P., New ferroelectric $\mathrm{Ba}_{1-x} \mathrm{M}_{x}\left(\mathrm{Li}_{2 x} \mathrm{Al}_{2-2 x}\right) \mathrm{O}_{4-4 x} \mathrm{~F}_{4 x}(\mathrm{M}=\mathrm{Pb}, \mathrm{Sr})$, Proc. IEEE Int. Symp. Appl. Ferroelectrics (1992) 360.

[48] Campet G., Claverie J., Perigord M., Ravez J., Portier J. et Hagenmuller P., Sur de nouvelles phases oxyfluorées dérivées du niobate de plomb : études cristallographiques et diélectriques, Mat. Res. Bull. 9 (1974) 1589.

[49] Ravez J. and Baudry H., Dielectric properties of some oxyfluoride ceramics and thick films, Commun. at the "Fourth European Meeting on Ferroelectricity" (Portoroz, Yougoslavie, 1979).

[50] Campet G., Claverie J , Hagenmuller P. et Perigord M., Caractérisations électriques de couches minces isolantes d'oxydes et d'oxyfluorures déposés par pulvérisation cathodique, Rev. Phys, Appl. 14 (1979) 415.

[51] Beauger A., Lagrange A., Houttemane C. et Ravez J., Propriétés de diélectriques ferroélectriques oxyfluorés. Application aux condensateurs céramiques multicouches, Proceeding of the International Conference on New Trends in Passive Compounds (Paris, 1982) p. 10.

[52] Desgardin G., Bajolet P., Raveau B. et Haussonne J., Le titanate de baryum en présence de fluorure de lithium : une nouvelle perovskite, Proceeding of the International Conference on New Trends in Passive Compounds (Paris, 1982) p. 18.

[53] Ravez J., Simon A., Rossignol J.F. et Hagenmuller P., Influence de l'addition de BaLiF 3 sur les propriétés diélectriques de $\mathrm{Pb}\left(\mathrm{Fe}_{0,5} \mathrm{Nb}_{0,5}\right) \mathrm{O}_{3}$, Rev. Chım. Min. 22 (1985) 377.

[54] Rossignol J.F., Simon A., Ravez J. et Hagenmuller P., Propriétés diélectriques de céramiques à base de $\mathrm{Pb}\left(\mathrm{Mg}_{1 / 3} \mathrm{Nb}_{2 / 3}\right) \mathrm{O}_{3}$ frittées à basse température grâce à l'ajout du mélange $\mathrm{Li}_{2} \mathrm{CO}_{3}-\mathrm{LiF}$, Ann. Chim. Fr. 10 (1985) 21.

[55] Abrahams S.C and Ravez J., Dielectric and related properties of fluorine-octahedra ferroelectrics, Ferroelectrics 135 (1992) 21. 